Effects of Atomic Radiation. New York : United Nations, 2000. 74 p.

8. Source-to-effects

Assessment for Radon in Homes and Workplaces. UNSCEAR 2006. Report : Annex E / United Scientific Committee on the Effects of Atomic Radiation. New York : United Nations, 2009. $138 \mathrm{p}$.

9. ICRP Publication 65.

Protection Against Radon-222 at Home and at Work. Annals of the ICRP. 1994 ; 23 (2) : 78 p.

10. ICRP Publication 115. Lung Cancer Risk from Radon and Progeny and Statement on Radon / ed. C.H. Clement. Annals of the ICRP. 2010 ; 40 (1) : $64 \mathrm{p}$.

11. Pavlenko T.O. Dovkillia ta zdorovia. 2007 ; 2 (41) : 22-25 (in Ukrainian).

12. Clavensjoe B. and Aakerblom G. Radon Book. Measures against Radon in Existing Buildings. Stockholm : FORMAS ; 2003 : 131p.

13. Normy radiatsiinoi bezpeky Ukrainy (NRBU-97) : Derzhavni hihiienichni normatyvy

[Standards of Radiation Safety of Ukraine (SRSU-97): State Hygienic Standards] DHN 6.6.1.6.5.001-98. Kyiv ; 1998 : 135 p.

(in Ukrainian).

14. Vymiriuvannia kontsentratsii radonu-222 u povitri budynkiv metodom pasyvnoi trekovoi radonometrii z vykorystannia pryladu «Track 2010Z». MVK 6.6.2.063-2000 : metodychni vkazivky z metodiv kontroliu

[Measurement of Radon-222 in the Indoor Air of Buildings by the Method of Passive Track Radonometry with the Help of «Track 2010Z». MIC 6.6.2.-0632000: Methodical Instructions on the Control Methods.

Ministry of Health Care of Ukraine]. Kyiv; $2000: 21$ p. (in Ukrainian).

15. Pavlenko T.O., Aksonov M.V., Fryziuk M.A. and Herman O.O. Metody protyradonovoho zakhystu budivel (ohliad) [Method of Anti-Radon Protection of Buildings (Review)]. In : Hihiiena naselenykh mists [Hygiene of Settlements]. Kyiv ; $2012 ; 60: 218-222$

(in Ukrainian).

16. Radon v pomeshchenii. Zashchita ot radona. [Indoor Radon. Protection from Radon]. URL : http://domekonom.su /2012/12/radon-zaschita.html

Надійшло до редакції 12.03.2018

\section{AWARENESS AND UNDERSTANDING OF THE THREATS FOR THE HEALTH OF THE BEHAVIORAL RISK FACTORS IN THE DEVELOPMENT OF NON-COMMUNICABLE DISEASES BY THE YOUNG PEOPLE AS AN IMPORTANT COMPONENT OF THE IMPLEMENTATION OF PREVENTIVE MEASURES} Serdiuk A.M., Gulich M.P., Koblianska A.V., Liubarska L.S. ОБІЗНАНСТЬ ТА УСВДОМЛЕННЯ МОЛОДДЮ ЗАГРОЗИ ДЛЯ ЗДОРОВ’Я ПОВЕДІНКОВИХ ФАКТОРІВ РИЗИКУ РОЗВИТКУ НЕІНФЕКЦЙНИХ ЗАХВОРЮВАНЬ - ВАГОМА СКЛАДОВА РЕАЛЗЗДІЇ ПРОФІЛАКТИЧНИХ ЗАХОДВ СЕРДЮК А.М., ГУЛІЧ М.П.,
КОБЛЯНСЬКА А.В.,
ЛЮБАРСЬКА Л.С.
ДУ «ІнстИтут громадського
здоров’я ім. О.М. Марзєєва УДК 613.97:613.2:316.62 Ключові слова: неінфекційні захворювання поведінкові фактори ризику, спосіб життя, обізнаність усвідомлення, опитувальні анкети. НАМН України», м. Київ асштабний тягар хронічних неінфекційних захворювань (НІ3), що охопив усі країни сучасного світу і демонструє тенденцію до зростання, негативно впливає як на здоров'я окремого громадянина, так і на громадське здоров'я суспільства загалом [1-3].

Вирішальну роль у формуванні негативних тенденцій у сфері громадського здоров'я
ОСВЕДОМЛЕННОСТЬ И ОСОЗНАНИЕ МОЛОДЕЖЬЮ УГРОЗЫ ДЛЯ ЗДОРОВЬЯ ПОВЕДЕНЧЕСКИХ ФАКТОРОВ РИСКА РАЗВИТИЯ НЕИНФЕКЦИОННЫХ ЗАБОЛЕВАНИЙ - ВАЖНАЯ СОСТАВЛЯЮЩАЯ РЕАЛИЗАЦИИ ПРОФИЛАКТИЧЕСКИХ МЕРОПРИЯТИЙ

Сердюк А.М., Гулич М.П., Коблянская А.В., Любарская Л.С ГУ «Институт общественного здоровья им. А.Н. Марзеева НАМН Украины», г. Киев, Украина

Актуальность обусловлена необходимостью изучения уровня осведомленности молодежи относительно факторов риска развития неинфекционных заболеваний и степени их распространенности для прогнозирования последствий реализации профилактических мер. Цель - определение уровня осведомленности студентов о поведенческих факторах риска развития неинфекционных заболеваний и осознание ими угрозы этих факторов для здоровья.

Материалы и методы. Проведен опрос студентов Киевского национального торгово-экономического университета по специальности «пищевая технология и товароведение» (выборка - 430 респондентов) об основних факторах риска развития неинфекционных заболеваний, а также осознания молодежью роли образа жизни для сохранения здоровья.

Результаты. Было показано, что о влиянии поведенческих факторов на развитие неинфекционных заболеваний осведомлено большинство студентов: о влиянии нерационального питания - 87,4\%, о недостаточной физической активности - 80,9\%, о злоупотреблении алкоголем и слабоалкогольными напитками - 92,2\%, о курении - 91,6\%. Однако эта осведомленность не приводит к осознанию угрозы для их здоровья: употребляют сладкие газированные и слабоалкогольные напитки (соответственно 68\% девушек, 92\% юношей; 65\% девушек, $71 \%$ юношей), каждая третья девушка (более 40\%) предпочитает выпивать чай или кофе с 2 и больше ложками сахара, употребляет 25 г и более соли в сутки, а также 25\% респондентов употребляют маргарины и спреды, около 25\% не употребляют ежедневно фрукты и овощи; курят сигареты и употребляют наркотики соответственно 23,8\% девушек, 43,7\% юношей и 10,3\% респондентов. Установлено, что только 55\% опрошенных указали об активном образе жизни и поддержании своей физической формы. Приведенное исследование свидетельствует о необходимости дальнейшего усовершенствования информационных и учебных программ для улучшения осведомленности и осознания молодожью опасности основных поведенческих факторов риска развития неинфекционных заболеваний.

Ключевые слова: неинфекционные заболевания, поведенческие факторы риска, образ жизни, осведомленность, осознание, опросные анкеты.

ㄷ Сердюк А.М., Гуліч М.П., Коблянська А.В., Любарська Л.С. СТАТТЯ, 2018. 
відіграють поведінкові фактори, які характеризують спосіб життя людини. Серед таких факторів значну роль у підвищенні ризику розвитку НІЗ мають нераціональне харчування, низька фізична активність, тютюнопаління, зловживання алкоголем [1].

Згідно зі стратегією ВООЗ профілактика НІ3 за рахунок корегування способу життя як напрямок збереження здоров'я населення набуває все більшого значення. Світовою практикою доведено, що існує реальна можливість проводити профілактику хронічних неінфекційних захворювань не тільки на індивідуальному рівні, але й на популяційному, насамперед серед молоді, за рахунок формування потреби у здоровому способі життя [4-6].

Обґрунтування ефективних заходів щодо попередження і зменшення впливу на здоров'я населення чинників ризику розвитку НІЗ вимагає вивчення сучасних особливостей та закономірностей їх поширеності серед різних груп населення (віково-статевих, соціальнопрофесійних тощо) шляхом проведення епідеміологічних досліджень для оцінки динаміки зрушень і корегування стратегічних орієнтирів та програмних заходів.

При цьому перевага надається дослідженням 3 одночасним визначенням декількох факторів ризику залежно від способу життя людини та факторів, що характеризують індивідуальний ризик. Саме такий підхід дасть змогу ефективно проводити профілактичні заходи, спрямовані на їх подолання. Але не менше значення для успішного проведення заходів запобігання розвитку НІЗ має обізнаність молоді щодо здорового способу життя та розуміння нею значення поведінкових факторів ризику у розвитку хронічних захворювань.

Спрямування зусиль щодо профілактики НІЗ на молодь це збереження потенціалу майбутнього здоров'я нації, можливість суттєво вплинути на формування здорового способу життя. Це відкриває перспективи реалізації загальнодержавних профілактичних заходів щодо неінфекційних захворювань [7].

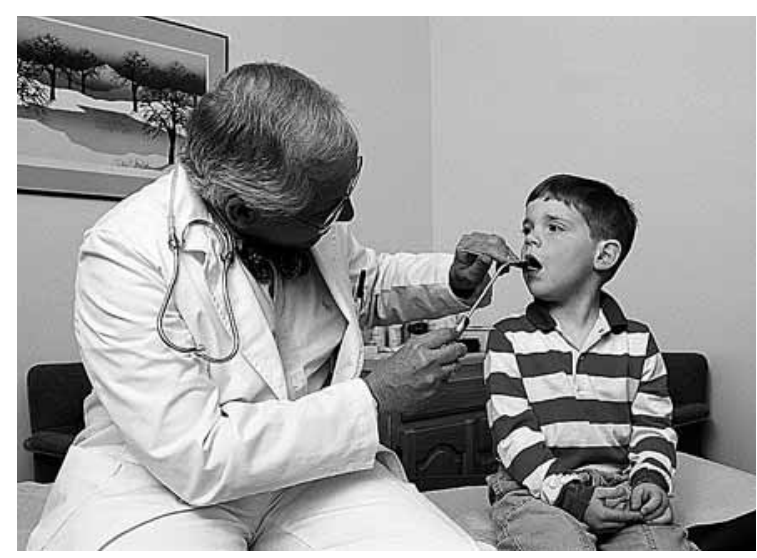

ГІГІЄНА ДІТЕЙ ТА ПІДЛІТКІВ Е

Серед молодого населення України студентська молодь $€$ специфічною верствою, особливості способу життя якої необхідно обов'язково враховувати. Сьогодні вона не захищена від ризикових форм поведінки: зловживання тютюном, алкоголем, наркотиками, а сучасний ритм навчання перешкоджає збалансованому і раціональному харчуванню [8]

Тому дуже важливим та необхідним $€$ проведення епідеміологічних досліджень, спрямованих на визначення рівня обізнаності молоді щодо факторів ризику розвитку НІЗ, а також вивчення ступеня поширеності у студентському середовищі таких поведінкових факторів ризику, як нераціональне харчування, низька фізична активність, тютюнопаління, зловживання алкоголем. Результати цих досліджень вкрай необхідні для прогнозування наслідків реалізації заходів профілактики НІЗ в Україні відповідно до цілей сталого розвитку на період до 2030 року.

Метою роботи було визначення рівня обізнаності студентів щодо поведінкових факторів ризику розвитку НІЗ та усвідомлення їх загрози для здоров'я.

Матеріали та методи досліджень. Дослідження проводились за допомогою анкетно-опитувального методу. Для цього авторами була розроблена та використана анкета, при створенні якої враховувались загальні принципи і правила ВООЗ [9].

Анкета відповідає міжнародним вимогам до такого роду документів, що можуть бути використані під час проведення аналізу [10-12].

В анкеті для визначення рівня обізнаності молоді щодо факторів ризику НІЗ були викори- стані безпосередні показники здорового харчування, фізичної активності, шкідливих звичок і усвідомлення молоддю ризику нездорового способу життя та обрано індикатори, які досить повно відбивають спектр проблеми.

Дослідження проводили одночасно у березні 2017 року у групі молодих людей - студентів Київського національного торгово-економічного університету (KHTEУ) за фахом «харчова технологія та товарознавство». Ми спрямували свої дослідження саме на цю категорію студентства тому, що у майбутньому саме вони мають формувати політику здорового харчування у сфері ресторанного господарства

Було роздано, отримано та оброблено 430 анкет. Усім респондентам, які брали участь в опитуванні, вручали анкети, які супроводжувалися детальним інструктажем 3 акцентуванням уваги на необхідності максимально точного їх заповнення.

При опитуванні вивчали не тільки обізнаність студентської молоді щодо поведінкових факторів ризику НІЗ, але й оцінювали ступінь поширеності факторів, що призводять до розвитку неінфекційних захворювань.

Отримані дані проаналізовано та оцінено з урахуванням статистичних методів аналізу [13].

Робота виконана у рамках запланованої НДР.

Результати та їх обговорення. Для оцінки рівня обізнаності студентів щодо впливу певних факторів ризику розвитку НІЗ респондентам було поставлено запитання «Чи відомо Вам, що факторами ризику НІЗ $€$ нераціональне харчування та зловживання сіллю, цукром, алкоголем, тютюнопаління, низька фізична активність?». 
Щодо споживання солі на добу, виявилося, що $31,5 \%$ юнаків і 25,8\% дівчат у груп обізнаних студентів споживають від 25 г і більше солі на добу. Відомо, що високий рівень споживання солі відіграє роль у підвищенні високого тиску, який є фактором ризику розвитку серцево-судинних захворювань. Тому ВООЗ рекомендує для виключення ризику щоденне споживання солі менше 5 г.

Аналіз відповідей респонден-

Аналіз відповідей опитаних показав, що більшість студентів обізнана щодо впливу цих факторів на ризик розвитку НІ3. $87,7 \%$ студентів вказали, що їм відомо про вплив нераціонального харчування на ризик розвитку НІ3; 80,9\% визнали недостатню фізичну активність, майже 92,0\% студентам відомо, що алкоголь тютюнопаління $€$ факторами ризику розвитку НІЗ.

Такий високий рівень обізнаності студентів КНТЕУ, напевно, пояснюється тим, що до навчальної програми цього інституту включено курс лекцій з основ здорового харчування та здорового способу життя.

З урахуванням таких високих відсотків обізнаності студентів щодо впливу цих факторів на ризик розвитку НІЗ було проведено аналіз відповідей респондентів щодо споживання овочів та фруктів, зловживання сіллю, цукром і продуктами, які містять транс-жири, а також оцінено власний досвід вживання алкогольних та слабоалкогольних напоїв, тютюну та наркотиків.

Відповіді обізнаних студентів залежно від статі свідчать, що $25,0 \%$ юнаків та 22,3\% дівчат не вживають щодня свіжі овочі та фрукти. Таким чином, чверть молоді підпадає під ризик розвитку НІЗ, адже, за оцінками ВОО3, низькій рівень споживання овочів та фруктів $є$ причиною випадків шлунково-кишкового раку - 19,0\%, випадків ішемічної хвороби серця $31,0 \%$ і 11,0\% випадків інсульту у світі [14-16].

Анкетуванням встановлено, що 25,8\% юнаків і дівчат вживають маргарини та спреди, які містять транс-ізомери жирних кислот, що пов'язано зі збільшенням ризику розвитку передусім серцевосудинних, онкологічних захворювань та діабету. тів свідчить про високий рівень споживання солодких газованих напоїв. Так, у групі обізнаних студентів щодня споживають солодкі газовані напої $92 \%$ юнаків та 68\% дівчат. Крім того, $41 \%$ юнаків та 29\% дівчат додають до чаю чи кави 2 та більше ложок цукру.

Такі дані викликають занепокоєння, адже надмірне споживання цукру та солодких газованих напоїв є однією з причин збільшення кількості людей, які страждають на ожиріння та цукровий діабет. За рекомендацією ВОO3, у раціоні харчування з енергетичною цінністю 2200-2500 ккал на добу кількість цукру має становити 50 г цукру. При цьому для отримання додаткового позитивного ефекту для здоров'я ВООЗ рекомендує знизити і цю кількість цукру. Потрібно враховувати, що велика частка цукру надходить до організму людини 3 солодкими напоями. Так, вміст цукру у літровій пляшці солодкого газованого напою становить 40 г (приблизно 10 чайних ложок) [17].

Проведене дослідження продемонструвало також поширення таких шкідливих звичок, як вживання алкогольних та слабоалкогольних напоїв, тютюнопаління та наркотиків.

Дослідження обізнаності та поширення шкідливих звичок дозволило встановити: 91,6\% опитаної студентської молоді відомо, що тютюнопаління суттєво впливає на розвиток НІ3, проте 28,0\% з них палять. Серед них 23,8\% становлять дівчата (83,0\% з них викурюють щодня від 1 до 10 сигарет) і $43,7 \%$ - юнаки. 3 них 67,0\% палять від 1 до 10 сигарет і, на жаль, 11,8\% викурюють від 10 до 20 сигарет на добу.

Більшість опитаних студентів $(92,2 \%)$ знає, що зловживання алкоголем $€$ фактором ризику
HI3, проте з цієї групи 65,0\% дівчат та 71,0\% юнаків періодично споживають алкогольні та слабоалкогольні напої.

Щодо власного досвіду студентів з вживання наркотиків, то $10,3 \%$ опитаних повідомили про досвід вживання наркотиків, серед яких 15\% юнаків і 9\% дівчат від загальної кількості. Отже, серед студентської молоді має місце вживання або була спроба вживати наркотики. При цьому цікавим $€$ той факт, що з 10,3\% респондентів, що мають досвід вживання наркотиків, лише 2\% позитивно ставляться до цього. Це дає надію, що кількість тих, що вживають наркотики, зменшуватиметься.

Вивчення обізнаності студентів про вплив фактора низької фізичної активності на ризик розвитку НІЗ показало, що значний відсоток $(80,9 \%)$ молоді знає про це. Проте лише $55,0 \%$ респондентів 3 цієї групи студентів усвідомлено ведуть активний спосіб життя та підтримують фізичну форму.

Оцінивши види спорту, якими найчастіше займаються студенти, ми встановили, що найбільший відсоток (58,0\% юнаків, 60,0\% дівчат) становили студенти, які відвідують тренажерні зали та займаються фітнесом.

Майже чверть студентів (25,5\% юнаків, 29,3\% дівчат) надають перевагу бігу як недорогому способу підтримки своєї фізичної форми.

Проте, на жаль, лише 4-5\% студентської молоді займаються плаванням.

Так, результати анкетування показали, що 55,0\% опитаної молоді надають перевагу активному способу життя та підтримують свою фізичну форму, проте значний відсоток студентської молоді не займається жодними видами спорту і не підтримує постійно свою фізичну форму. Це може бути пов'язаним з відсутністю чіткої мотивації та усвідомлення потреби у таких заняттях.

\section{Висновки}

1. Встановлено, що значний відсоток опитаних студентів обізнаний, що нераціональне харчування $(87,4 \%)$, недостатня фізична активність (80,9\%), зловживання алкогольними та слабоалкогольними напоями $(92,2 \%)$, а також тютюнопалін- 
AWARENESS AND UNDERSTANDING OF THE THREATS FOR THE HEALTH OF THE BEHAVIORAL RISK FACTORS IN THE DEVELOPMENT OF NON-COMMUNICABLE DISEASES BY THE YOUNG PEOPLE AS AN IMPORTANT COMPONENT OF THE IMPLEMENTATION OF PREVENTIVE MEASURES Serdiuk A.M., Gulich M.P., Koblianska A.V., Liubarska L.S.

SI «O.M. Marzeiev Institute for Public Health of the NAMSU», Kyiv, Ukraine

Background: The topicality is stipulated by the necessity for the study both the level of the awareness of young people regarding risk factors of the development of non-communicable diseases and the level of their prevalence for the prediction of the consequences of the implementation of preventive measures.

Objective: We determined the level of the awareness of the students about behavioral risk factors for the development of non-communicable diseases and understanding of the threats of these factors by them.

Materials and methods: We performed the questionary in the students (430 respondents) of the Kyiv National Trade and Economic University in the speciality: food technology and commodity science about main risk factors for the development of non-communicable diseases and understanding of the role of the lifestyle for the health preservation in the young people.
Results: The majority of the students was shown to be aware of the influence of the behavioral factors on the development of non-communicable diseases, the effect of inefficient nutrition $-87.4 \%$, insufficient physical activity $-80.9 \%$, alcohol and low-alcohol beverages - 92.2\%, smoking - 91.6\%. However, this awareness does not lead to understanding of the threat for their health: they consume sweet fizzy and low-alcohol beverages (68\% of the girls, $92 \%$ of the boys, $65 \%$ of the girls, $71 \%$ of the boys, respectively), every third girl and over $40 \%$ prefer to drink tea or coffee with 2 or more spoons of sugar, use 25 grams and more salt daily, and $25 \%$ of the respondents consume margarines and spreads, about $25 \%$ do not consume fruits and vegetables every day, $23.8 \%$ of the girls, $43.7 \%$ of the boys, and $10.3 \%$ of the respondents smoke cigarettes and use drugs. Only 55\% of the respondents were estimated to point to an active lifestyle and maintaining of their physical form.

The study indicates the need for the further improvement of the information and training programs to improve the awareness and understanding of the dangers of the main behavioral risk factors for the development of non-communicable diseases by the young people.

Keywords: non-communicable diseases, behavioral risk factors, lifestyle, awareness, understanding, questionnaires. ня $(91,6 \%)$ є факторами ризику розвитку неінфекційних захворювань. Проте така обізнаність не призводить до усвідомлення ними загрози цих факторів для здоров'я.

2. Визначено, що велика частина студентської молоді не усвідомлює шкоду від зловживання сіллю $(25,8 \%$ дівчат, $31,5 \%$ юнаків), цукром (29,0\% дівчат, 41,0\% юнаків), солодкими газованими напоями (68\% дівчат, 92,0\% юнаків), маргаринами і спредами (25,8\% дівчат і юнаків) та недостатньої кількості щоденного споживання свіжих фруктів і овочів (22,3\% дівчат, $25,0 \%$ юнаків), що може збільшити ризик розвитку НІЗ.

3. Виявлено, що серед студентської молоді, обізнаної щодо впливу шкідливих звичок на розвиток НІЗ, періодичне споживання алкогольних та слабоалкогольних напоїв $(65,0 \%$ дівчат, $71,0 \%$ юнаків), тютюнопаління (23,8\% дівчат, 43,7\% юнаків). 10,3\% респондентів повідомили про досвід вживання наркотичних речовин, серед яких 15,0\% юнаків і 9,0\% дівчат.

4. Визначено, що серед кількості студентів, які обізнані відносно ролі фізичної активності у розвиткові НІ3, лише $55,0 \%$ надають перевагу активному способу життя та займаються підтримкою своєї фізичної форми.

5. Встановлено необхідність подальшого доопрацювання та удосконалення інформаційних і навчальних програм для молоді й студентів з метою покращання їхньої обізнаності та усвідомлення небезпеки основних поведінкових факторів ризику розвитку НІЗ з точки зору збереження подальшого здоров'я.

ЛІТЕРАТУРА

1. Неинфекционные заболевания. Информационный бюллетень. Апрель 2017 г. Режим доступа : http://www.who. int/mediacentre/factsheets/ fs355/ru/.

2. Достижение девяти глобальных целей по НИЗ, общая ответственность: Доклад о ситуации в области неинфекционных заболеваний в мире, 2014 / Всемирная организация здравоохранения. 2014. 16 с.

3. Европейский план действий в области пищевых продуктов и питания на 2015-2020 годы. URL : http://www.euro. who.int/ru/health-topics/disease-prevention/nutrition/publications/2015/european-foodand-nutrition-action-plan20152020

4. Стратегия предупреждения хронических заболеваний в Европе. Основное внимание - действиям общества по укреплению общественного здоровья. Видение стратегии с позиции CINDI / Всемирная организация здравоохранения. Копенгаген,

2005. 64 c

5. Сердюк А.М., Полька.Н.С., Гуліч М.П. Профілактика неінфекційних захворювань, що пов'язані зі способом життя, особливостями харчування та фізичною активністю вагомий напрям національної стратегії охорони здоров'я населення України.

Журнал Академії медичних наук. 2010. Т. 16. № 2.

C. 299-307.

6. Гуліч М.П., Коблянська А.В. Профілактика неінфекційних захворювань та боротьба з факторами ризику їх розвитку: підходи до впровадження заходів Глобальної стратегії ВООЗ запобігання і контролю неінфекційних захворювань в Україні. Довкілля та здоров'я. 2010. № 2. С. 57-62.

7. Осуществление концептуального видения политики Здоровье-2020 : стратегическое руководство в интересах здоровья в XXI веке.

Реализация задуманного / Всемирная организация здравоохранения. 2014. 108 с. 
16. Питание и здоровье в Европе. Резюме / Европейское региональное бюро ВОЗ Копенгаген, 2003. 38 с. URL : http: // www. euro. who.int/ document/e78578r. Pdf

17. WHO Guideline: Sugars intake for adults and children. URL : /http://www.who.int/nutrition/publications/guidelines/sug ars intake/ru/.

18. Балакірєва О.М., Бондар Т.В., Артюх О.П. та ін. Стан та чинники здоров'я українських підлітків : моногр. К. : ЮНІСЕФ; Укр. ін-т соц. досліджень ім. О. Яременка, 2011. 172 c

REFERENCES

1. Noncommunicable diseases. Fact sheets April 2017. URL : http://www. who.int/mediacentre/factsheets/fs355/ru/.

2. WHO Global status report on noncommunicable diseases 2014 : Attaining the nine global noncommunicable diseases targets; a shared responsibility. 2014.

3. European Food and Nutrition Action Plan 2015-2020. /WHO, 2014. 40 p. URL : http://www. euro.who.int/ru/heal th-topics/disease-

prevention/nutrition/publica tions/2015/european-food-andnutrition-action-plan-20152020

4. A Strategy to Prevent Chronic Disease in Europe. A Focus on Public Health Action. The CINDI Vision. Copenhagen ; 2005. 64 p.

5. Serdiuk A.M., Polka N.S. and Gulich M.P. Zhurnal Akademii medychnykh nauk. $2010 ; 16$ (2) : 299-307 (in Ukrainian)

6. Gulich M.P. and Koblianska A.V. Dovkillia ta zdorovia. $2010 ; 2$ : 57-62 (in Ukrainian).

7. Implementing a Health 2020 Vision: Governance for Health in the 21-st Century. Making it Happen. WHO ; 2013 : 92 p.

8. Molod v sviti, shcho zminiuetsia [Young People in a Changing World]. Geneva : UNICEF ; 2000 : 44 p.

(in Ukrainian).

9. The World Health Organization Quality of Life (WHOQOL) - BREF / WHO, 2004. URL : (http : // www. who.int/ substance abuse/research tools/eñ/russian whoqol.pdf).

$1 \overline{0}$. Kachestvennye indicatory dlia monitoring dostizheniia tselevykh orientirov politiki
Zdorovie-2020 [Qualitative Indicators for Monitoring Health 2020 Policy Targets].

Copenhagen : WHO ; 2014.

50 p. (in Russian).

11. Razrabotka pokazatele dlia tselevykh orientirov politiki Zdorovie-2020. Pervoe soveshchanie gruppy ekspertov [Developing Indicators for the Health 2020 Targets (Utrecht, Netherland, 18-19.2012)]. WHO ; 2016 : 43 p. URL : (http : // www.euro.who.int/data/assets/ pdf fi le/0016/172510/

Developing-indicators-for-theHealth-2020-targets-Rus.pdf).

12. Doklad o sostoianii zdravookhraneniia v Evrope 2015. Tselevye orientiry I bole shyrokaia perspektiva - novye rubezhi v rabote s fakticheskimi dannymi [The European Health

Report 2015. Targets and Beyond - Reaching New Frontiers in Evidence]. WHO ; 2015. URL : http : //

www.euro.who.int/_data/assets/ pdf file/0006/293739/

European-health-report-2015full-book-ru.pdf?ua=1 (in Russian).

13. Antomonov M.Yu. Matematicheskaia obrabotka i analiz medico-biologicheskikh dannykh [Mathematical Processing and Analysis of Medico-Biological Data]. Kiev ; 2006 : 558 p. (in Russian).

14. Promoting Fruit and Vegetable Consumption Around the World. URL

:http://www.who.int/dietphysicalactivity/fruit/ru/index1.html

15. Global Strategy on Diet, Physical Activity and Health.

WHO ; 2004

16. Pitanie I zdorovie v Evrope. Novaia osnova dlia deistvii resume [Food and Health in Europe : a New Basis for Action]. Copenhagen : WHO Regional Office for Europe ; 2003. 38 p. URL : http: // www. euro. who.int/

document/e78578r. Pdf (in Russian).

17. Guideline: Sugars intake for adults and children. WHO ; 2015. $59 \mathrm{p}$

18. Balakirieva O.M. Bondar T.V., Artiukh O.P. et al. Stan ta chynnyky zdorovia ukrainskykh pidlitkiv : monografiia [State and Factors of the Health of the Ukrainian Adolescents : Monograph]. Kyiv : UNICEF ; 2011 : 172 p.

(in Ukrainian).

Надійшло до редакції 22.03.2018 питанию, физической активности и здоровью. ВОЗ, 2004. 18 с. 